\title{
DISTRIBUTION OF EXTRACELLULAR POLYMERIC SUBSTANCES AND THEIR ROLE IN AEROBIC GRANULE FORMATION
}

\author{
Korneliusz Miksch, Beata Kończak \\ Silesian University of Technology, Faculty of Power and Environmental Engineering, \\ Environmental Biotechnology Department, Akademicka 2, 44-100 Gliwice, Poland
}

\begin{abstract}
This study investigated the quantity and distribution of extracellular polymeric substances (EPS) in aerobic granules. Results showed that EPS play an important role in the formation and stabilisation of granules. The content of EPS significantly increases during the first weeks of biogranulation. An analysis of EPS in the granules revealed that the protein level was 5 times higher than in polysaccharides. The increase of protein content correlated with the growth of cell hydrophobicity $\left(r^{2}=0.95\right)$. EPS and hydrophobicity are important factors in cell adhesion and formation of granules.
\end{abstract}

\begin{abstract}
The aim of this work was also to determine the distribution of EPS in the granule structure. In situ EPS staining showed that EPS are located mostly in the center of granules and in the subsurface layer. The major components of the EPE matrix are proteins, nucleic acids and $\beta$-polysaccharides. These observations confirm the chemical extraction data and indicate that granule formation and stability are dependent on protein content.
\end{abstract}

Keywords: aerobic granule, extracellular polymeric substances, staining

\section{INTRODUCTION}

The aerobic granular system is regarded as one of the most useful and promising technologies for compact wastewater treatment plants. The application of granules in wastewater treatment shows many advantages, such as high biomass retention, high conversion capacity, reduced biomass production, excellent settleabilty and resistance to inhibitory and toxic compounds (Kong et al., 2009; Liu et al., 2004). Aerobic granules are spherical compact aggregates of microorganisms cultivated in a granular sequencing batch reactor (GSBR) (Arrojo et al., 2004; Liu et al., 2010b; Morgenroth et al., 1997; Wojnowska-Baryła et al., 2010). The formation of aerobic granules is influenced by: specific substrate composition, feast-famine regime, relatively high hydrodynamic shear force and a short settling time (Kończak and Miksch, 2011a).

A positive impact on aerobic granulation is also exerted by the presence of extracellular polymeric substances, such as exoprotein, exopolysaccharides or extracellular DNA (eDNA) (Kończak and Miksch, 2011b; Tian, 2008; Wang et al., 2006). EPS favour the gelation process, cell aggregation and granule formulation (Seviour et al., 2009). They form a specific type of cellular protection and may also function as the source of easily assimilated organic carbon in nutritional deficiencies (Laspidou et al., 2002). The expression of extracellular polymers is a common phenomenon in the natural world and constitutes the life strategy for the majority of microorganisms. In the studies thus far it has been determined that in the presence of the EPS matrix the cell hydrophobicity increases, keeping the

*Corresponding author, e-mail: Korneliusz.Miksch@polsl.pl 
granule structures intact (Liu et al., 2003). However, the question of which EPS matrix component plays the key role in biogranulation processes, remains unanswered. The main objective of this study was to determine the role of proteins and polysaccharides in the formation of aerobic granules.

The second objective of this study was to gain a comprehensive outlook on the localisation of EPS in aerobic granules. A confocal laser scanning microscopy (CLSM) with adapted fluorescence marking was used to visualise the detailed architecture of the EPS matrix.

It is expected that the information provided herein would be useful to further the understanding of the role of EPS in aerobic granule formation, and to facilitate the application of aerobic granulation technology in wastewater treatment.

\section{METHODS AND MATERIALS}

\subsection{Reactor operations}

2-liter column-type SBRs was operated for 3 months to cultivate aerobic granular sludge. The internal diameter of the reactor was $83.5 \mathrm{~mm}$, the height was $565 \mathrm{~mm}$ and the reactor working $H / D$ ratio was about 6.8. Fine air bubbles for aeration were supplied through an air diffuser at a rate of 2,6 liters $\mathrm{min}^{-1}$. The reactor was working with a 50\% volumetric exchange ratio. It was inoculated with 4 liters of activated sludge from a municipal wastewater treatment plant in Gliwice, Poland. The reactor was fed with a synthetic wastewater. The following substances were used in the experiments $(\mathrm{g} / \mathrm{L})$ : COD (sodium acetate) $0.543 ;\left(\mathrm{NH}_{4}\right)_{2} \mathrm{SO}_{4} 0.075 ; \mathrm{KH}_{2} \mathrm{PO}_{4}$ 0.075. A trace solution was added to the feeding media $(\mathrm{g} / \mathrm{L}): \mathrm{H}_{3} \mathrm{BO}_{3} 0.05 ; \mathrm{ZnCl}_{2} 0.05 ; \mathrm{CuCl}_{2} 0.03 ; \mathrm{MnSO}_{4} \cdot \mathrm{H}_{2} \mathrm{O} 0.05 ;\left(\mathrm{NH}_{4}\right)_{6} \mathrm{Mo}_{7} \mathrm{O}_{24} \cdot 4 \mathrm{H}_{2} \mathrm{O} 0.05$; $\mathrm{AlCl}_{3} 0.05 ; \mathrm{CoCl}_{2} \cdot 6 \mathrm{H}_{2} \mathrm{O} ; \mathrm{NiCl}_{2}$ 0.05. Organic loading rate was $1.2 \mathrm{~kg}$ of chemical oxygen demand (COD) $\mathrm{m}^{-3}$ day $^{-1}$ (300 mg of COD liter ${ }^{-1}$ cycle $^{-1}$ ). The total cycle time was $8 \mathrm{~h}$ with four cycles per day (3-min filling, 168-min aeration, 5- min settling, 3-min drawing, and 1-min idle).

\subsection{Analytical procedures}

\subsubsection{Biomass analysis}

Total suspended solids (TSS) and volatile suspended solids (VSS) were analysed in accordance to the standard methods (Clesceri et. al., 1999). Sludge volume index (SVI) was assessed in accordance to modified standard methods by measuring the volume of sludge after 5 and $30 \mathrm{~min}$ of sedimentation.

The development of granules was observed by using a optic microscope (Motic 245A) and images were obtained with an attached Moticam BA400 digital camera. Hydrophobocity of biomass was determined according to the metod by Rosenberg et al. (1980).

\subsubsection{Extracellular polymeric substances (EPS) extraction and chemical analysis}

The sludge samples were centrifuged at $4^{\circ} \mathrm{C}$ and $2000 \mathrm{~g}$ for $15 \mathrm{~min}$. The collected bottom sediments were resuspended in $0.1 \mathrm{M}$ PBS buffer $(p H 7.5)$ for extraction of tighly bound EPS (TB-EPS). TB-EPS were extracted using a cation-exchange resin according to the method of Frølund et al. (1996). The dosis of Dowex resin (50x8, $\mathrm{Na}^{+}$form, 20-50 mesh, Sigma Aldrich) was $60 \mathrm{~g} / \mathrm{gVSS}$. The samples were stirred at $750 \mathrm{rpm}$ for $1 \mathrm{~h}$ in the dark at $4^{\circ} \mathrm{C}$. Then, the samples were centrifuged at $4{ }^{\circ} \mathrm{C}$ and $20,000 \mathrm{~g}$ for $20 \mathrm{~min}$ and collected supernatants were filtered through a $0.45 \mu \mathrm{m}$ membrane of cellulose acetate. The carbohydrate content of TB-EPS was measured by the phenol-sulphuric method using glucose as the standard (Dubois et al., 1956). The content of protein in the TB-EPS was measured using 
fluorescent dyes binding to protein (Quant-IT, Invitrogen). The fluorescence intensity of the resulting complex depends directly on the amount of protein in the sample.

\subsubsection{Confocal laser scanning microscopy (CLSM)}

Fresh and fully hydrated and mature aerobic granules were taken from the reactor and embedded in cryosectioning compound and cryosectioned into $20-\mu \mathrm{m}$ sections (Cryostat, Leica). Then, the cryosection, cut $120 \mu \mathrm{m}$ below the granule surface, was stained in 1.5-ml Eppendorf tubes, covered with aluminum foil, and placed on a shaker table $(100 \mathrm{rpm})$. Calcofluor white (Sigma Aldrich) was used to stain $\beta$-D-glucopyranose polysaccharides. The fluorescein isothiocyanate (FITC) (Fluka) was apllied to FITC to stain the protein fraction in the granules. SYTO 63 (Invitrogen) was utilised to stain nucleic acid. Calcium Green (Invitrogen) was added to stain calcium ions in the structure of matrix EPS. According to Adav et al. (2010) the staining procedure was as follows: The sample was washed two-three times with sterile distilled water and then suspended in $1 \times$ PBS buffer. Specifically, SYTO $63(20 \mu \mathrm{M}$, in $1 \times$ PBS buffer, $p H$ 7.2) was first added to the sample and shaken on a shaker table for $30 \mathrm{~min}$. The excess dye solution was removed by washing with $1 \times \mathrm{PBS}$ buffer. Then, $0.1 \mathrm{~mol} \mathrm{NaHCO}_{3}$ buffer $(100 \mu \mathrm{l})$ was added to maintain the amine group in non-protonated form, followed by a FITC solution $(1 \mathrm{mg} / \mathrm{ml}$ in DMSO), and the sample was incubated on a rotary shaker for $30 \mathrm{~min}$. After staining the excess stain was removed by PBS buffer. Calcofluor white $(30 \mathrm{mg} / \mathrm{ml}$, in $1 \times$ PBS buffer, $p H$ 7.2) was then added for $30 \mathrm{~min}$, and then a Calcium Green $(0.12 \mathrm{mg} / \mathrm{ml}$ in DMSO) was added for another $30 \mathrm{~min}$. After each of these two staining steps, the sample was washed with PBS solution to remove excess stain.

The sample was visualised with a microscop Zeiss LSM500 with diode laser $405 \mathrm{~nm}$, Ar458/477/488/514 nm, HeNe laser $633 \mathrm{~nm}$. Images were anylased using the ZEN 2008 software (Zeiss).

\subsubsection{Correlation analysis}

Also, a correlation analysis between two variables was performed, establishing the linear regression line. The degree of linear correlations between the volume of expressed EPS and the hydrophobicity was determined by calculating Pearson's correlation coefficient. The significance of correlation coefficients was determined using critical value tables for correlation coefficient (Gołaszewski et al., 2003). Correlations were considered statistically significant with $p<0.05$.

\section{RESULTS}

\subsection{Reactor operation and performance}

First, granules with a diameter in the range of $0.1-0.3 \mathrm{~mm}$ were observed in the reactor after one week of operation (Fig. 1a). At this time, also flocs were observed with a diameter of approximately $0.01-$ $0.085 \mathrm{~mm}$ (Fig. 2).

In subsequent days the mean diameter of granules increased. After 60 days of granulation, there were granules in the reactor with diameters in the range of $3-29 \mathrm{~mm}$ (Fig. 1b, Fig. 2). In this period the biomass concentration stabilised at $4.6-4.9 \mathrm{~g}_{\mathrm{vss}} / \mathrm{L}$ (Fig. 3). 
a)

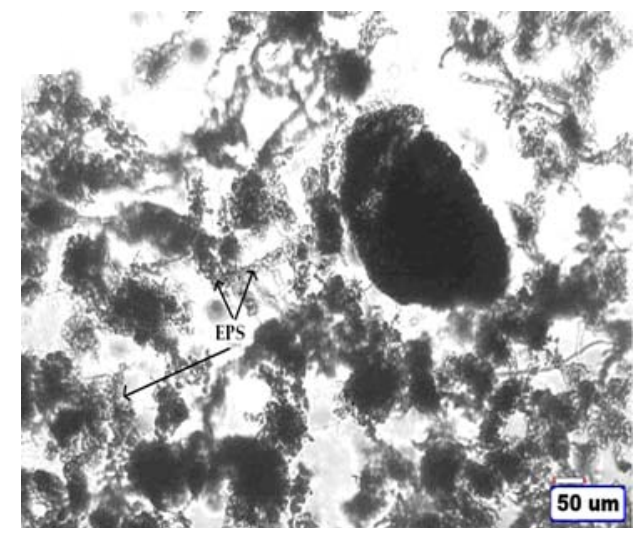

b)

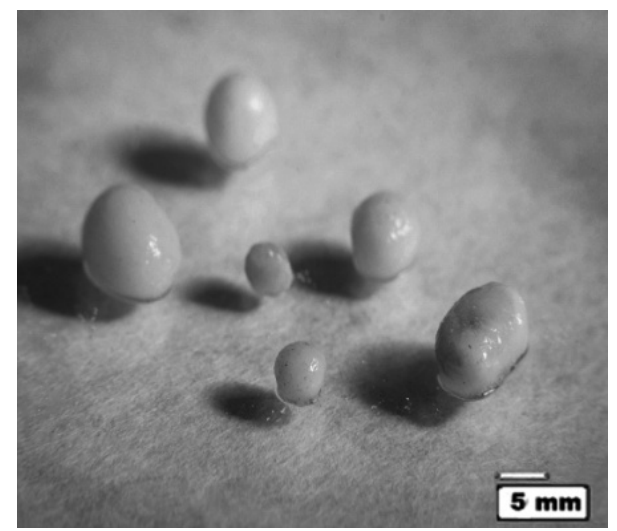

Fig. 1. Pictures of the granules: days 7 (a) and 60 (b)

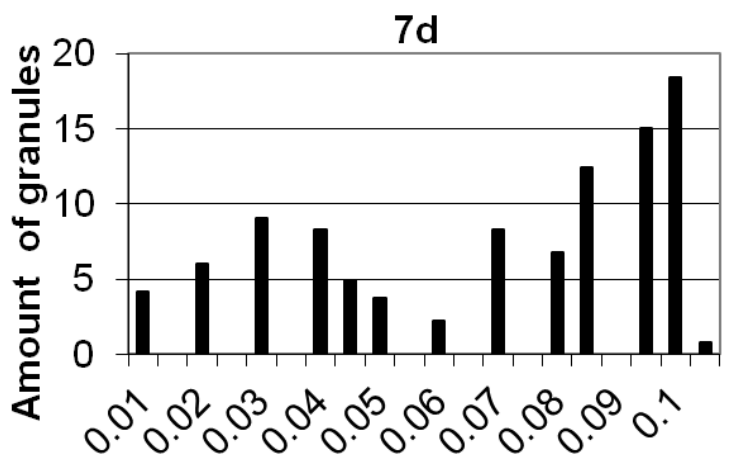

diameter $[\mathrm{mm}]$

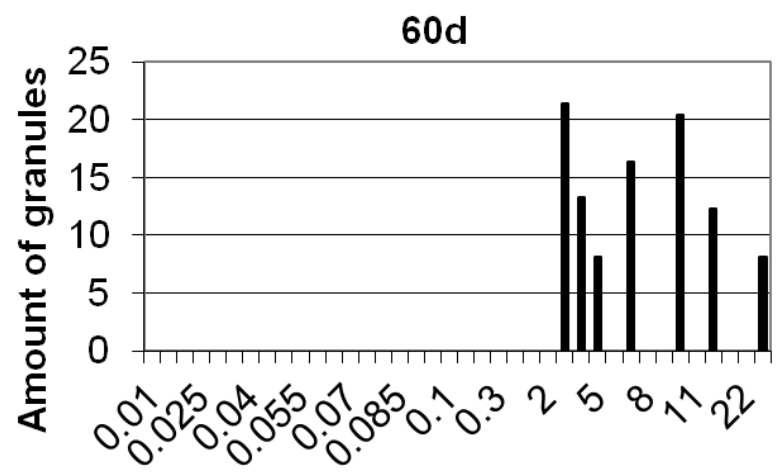

diameter [mm]

Fig. 2. Increment of floc and granule diameter in the reactor in 7 and 60 days of granulation

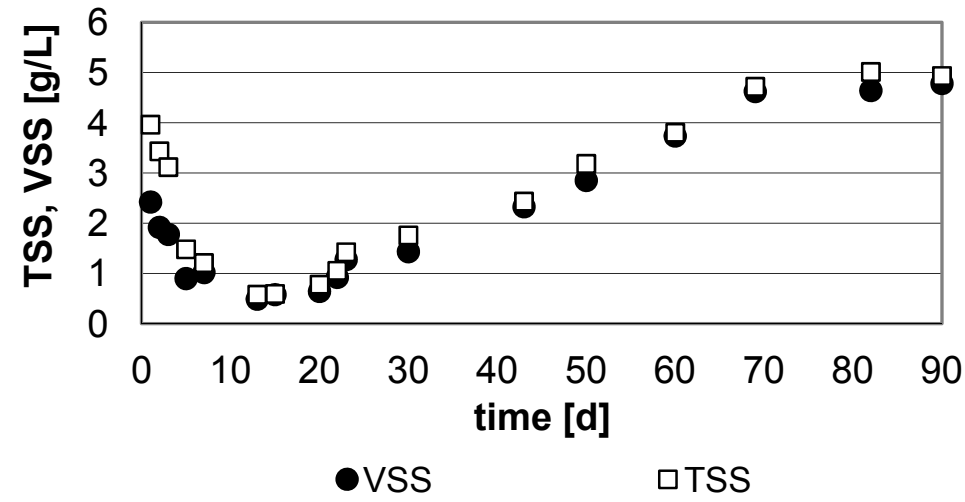

Fig. 3. Evolution of total and volatile suspended solids (TSS, VSS) in the reactor effluent

When mature granules were present in the reactor, it was observed that the suspended biomass was washed out from the reactor to a minor extent only (the total suspended solid content (TSSeff) on the effluent from day 13 was approx. $0.04 \mathrm{~g} / \mathrm{L}$ ) (Fig. 4a).

Sludge granulation had a positive impact on the sludge volume index (SVI), which decreased from 129 $\mathrm{cm}^{3} / \mathrm{g}$ to $50 \mathrm{~cm}^{3} / \mathrm{g}$ and remained at $49-73 \mathrm{~cm}^{3} / \mathrm{g}$ for the rest of the process. Since day 12 the observed $\mathrm{SVI}_{5} / \mathrm{SVI}_{30}$ ratio was 1-1.1 (Fig. 4b), which confirms very good sedimentation properties of the granules. 

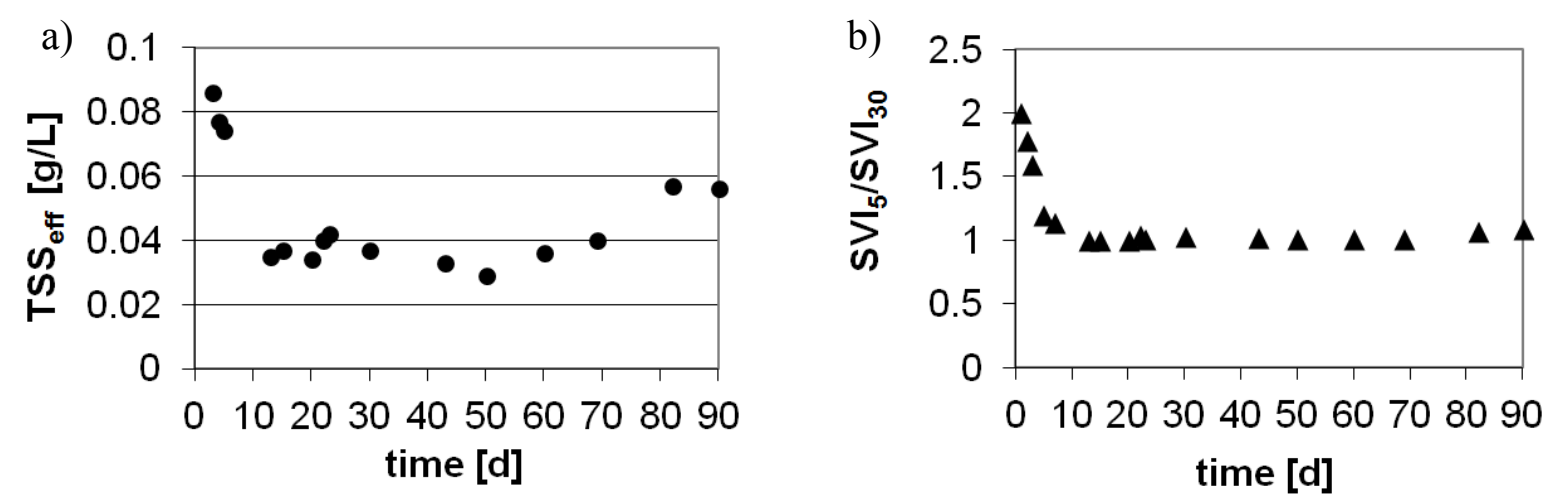

Fig. 4. a) Evolution of total (TSS) and volatile (VSS) suspended solid content during biogranulation,

b) Change of the $\mathrm{SVI}_{5} / \mathrm{SVI}_{30}$ ratio

\subsection{Secretion of EPS}

Microorganisms intensively produce EPS since the first moment they come under the strong influence of hydrodynamic forces until the formation of first stable granules, i.e. approx. until day 13 (Fig. 5). Next, the excess of extracellular polymers undergo rapid degradation, which produces energy used for biomass and granule growth. In the granule stabilisation period the EPS content again, although very slowly, increases (Fig. 5).

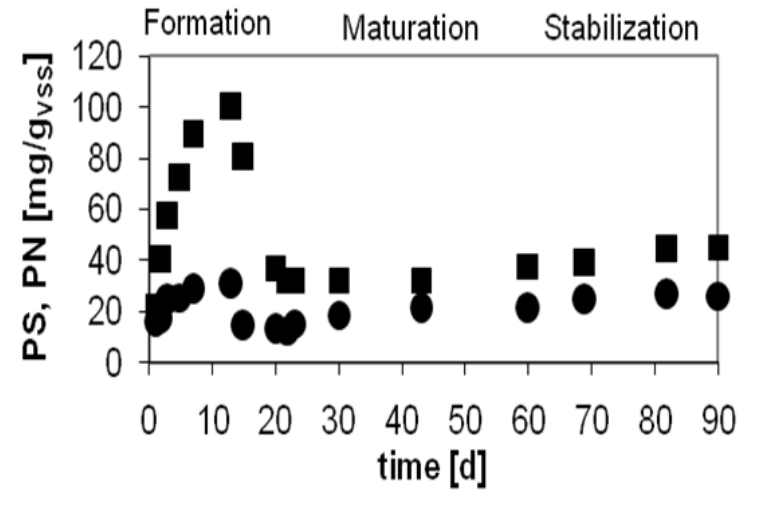

- Proteins (PN) Polysaccharides (PS)

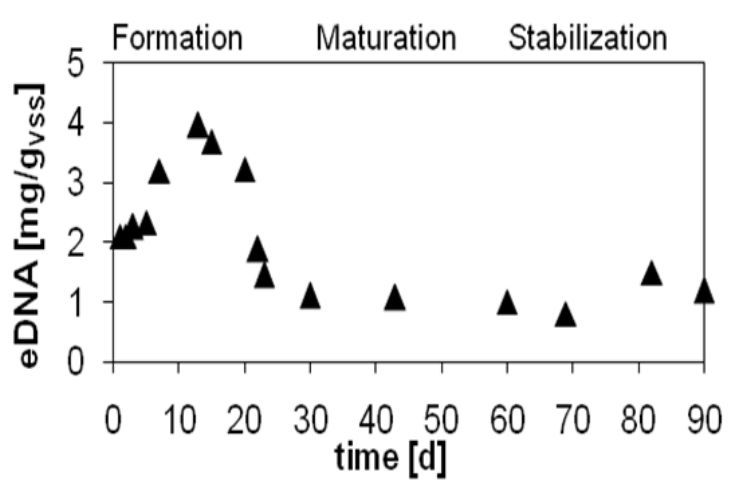

$\Delta$ extracellular DNA (eDNA)

Fig. 5. Change of proteins (PN), polysaccharides (PS) and extracellular DNA (eDNA) content of TB fraction during biogranulation

The studies indicated that proteins are the most numerous granule components. At the key moment of biogranulation their content may be up to 5 times higher that of polysaccharides (Fig. 5), which, on the other hand, suggests their crucial role in the biogranulation process. The statement above is substantiated also by a stronger correlation between the change of cell hydrophobicity and the intesiveness of protein expression than in the case of polysaccharides. The relationship between the concentration of extracellular polypeptides and hydrophobicity was almost linear $\left(r^{2}=0.95\right)$, and the correlation coefficient between those variables was high $(r=0.97)$ and statistically significant (Fig. 6, Tab.1). 

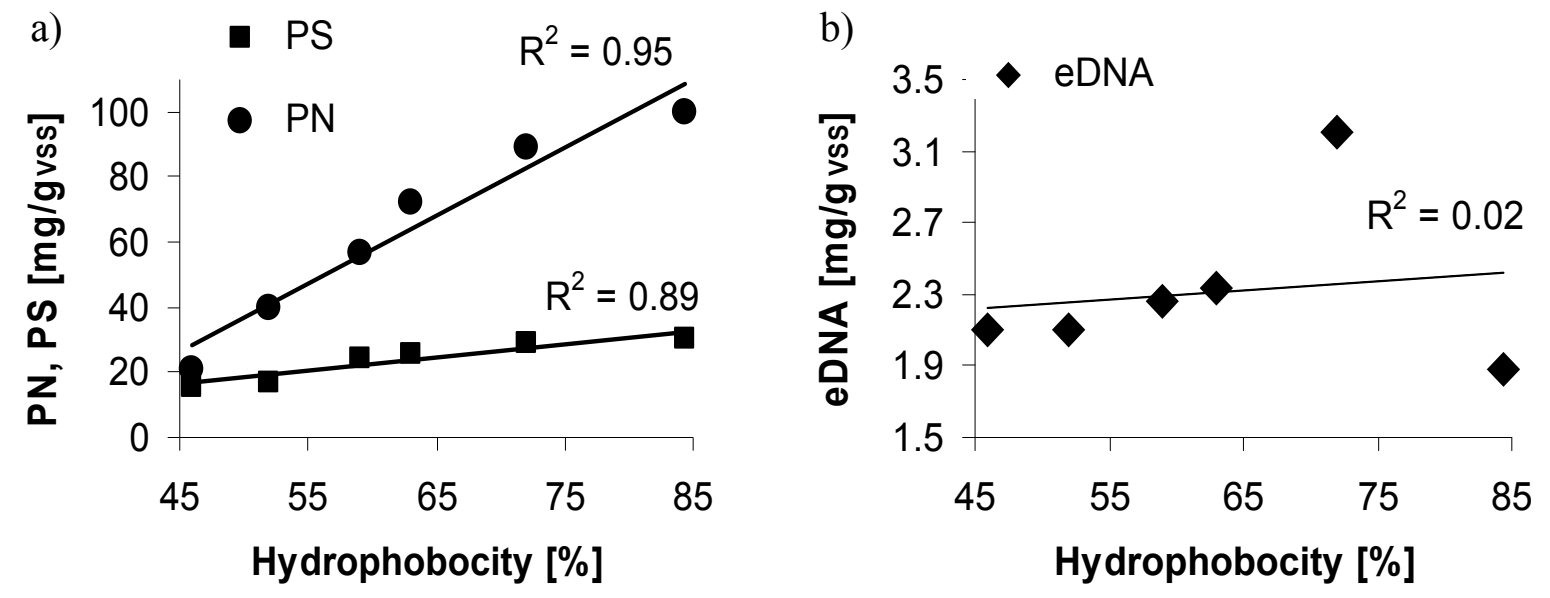

Fig. 6. The linear correlation between the concentrations of PS, PN (a) and eDNA (b) and the hydrophobicity during granules formation

Table 1. The r-squared values and the correlation coefficient between the concentration of PN, PS and eDNA and hydrophobicity

\begin{tabular}{|c|c|c|}
\hline & $r^{2}$ & $r$ \\
\hline PN & 0.95 & 0.97 \\
\hline PS & 0.89 & 0.94 \\
\hline eDNA & 0.02 & 0.15 \\
\hline
\end{tabular}

Furthermore, during the granule maturing period a drop in hydrophobicity is observed, associated with the fact that microorganisms probably utilise the expressed EPS for the purposes of granule restructuring and reorganisation. Therefore, EPS have a significant impact on cell hydrophobicity (Fig. 7). In general, these results are in good agreement with results found in previous studies. For example, Zhang et al. (2007) also reported that proteins are the main compounds of EPS matrix and that the PN/PS ratio was increased from to 2.3 to 4.9 during biogranulation. The changes in cell hydrophobicity were positively correlated with PN/PS values, and the related coefficient was 0.969 .

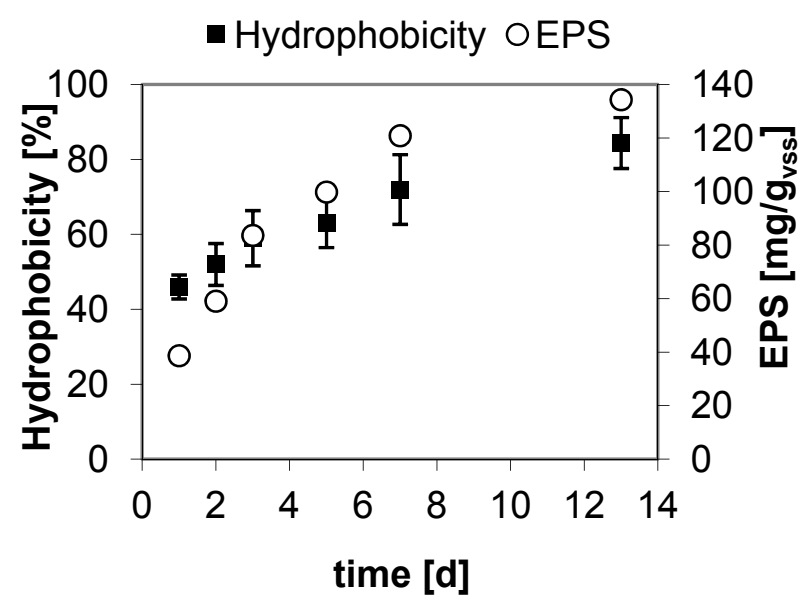

Fig. 7. EPS and hydrophobicity evolution during granulation. PN - proteins, PS - polysaccharides, eDNA - extracellular DNA 


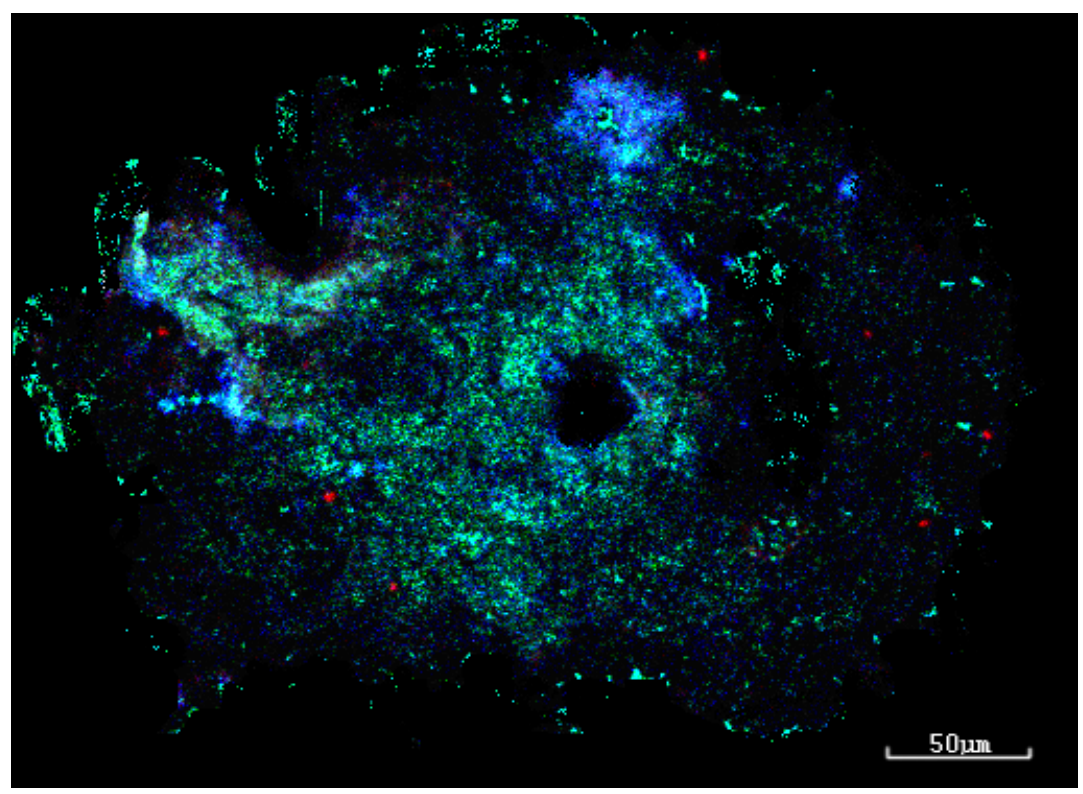

Fig. 8. Fluorescent staining of 20- $\mu \mathrm{m}$ cryosections. The figure shows cells stained with Syto 63 (red), $\beta$ polysaccharides stained with CW (blue), proteins stained with FITC (green), and calcium ions stained with

Calcium Green (yellow). Images were captured with the objective of 10x magnification

A. Calcium ions

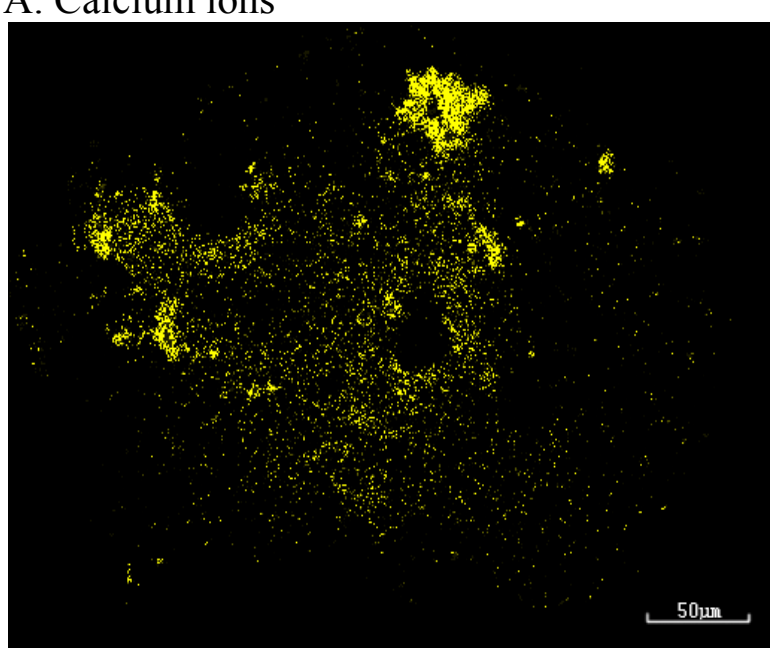

\section{Proteins}

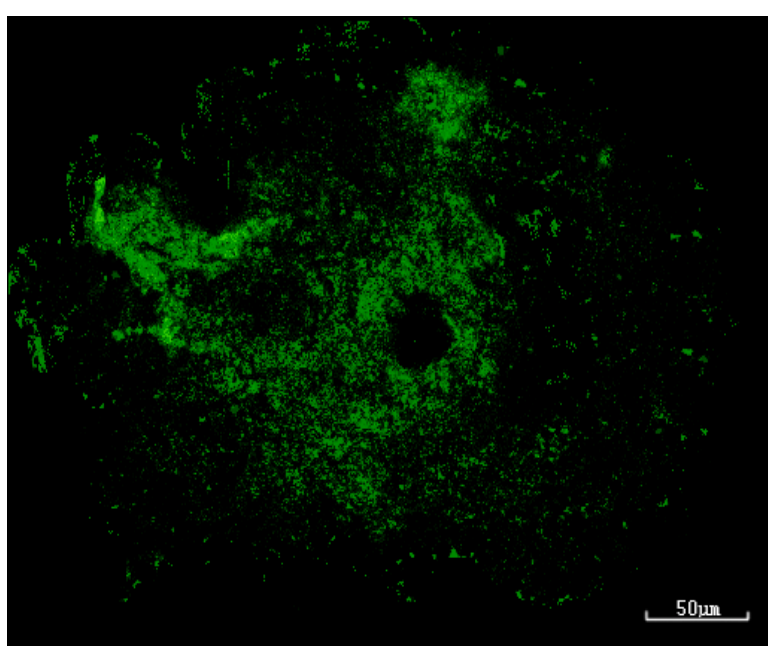

B. $\beta$ - polysaccharides

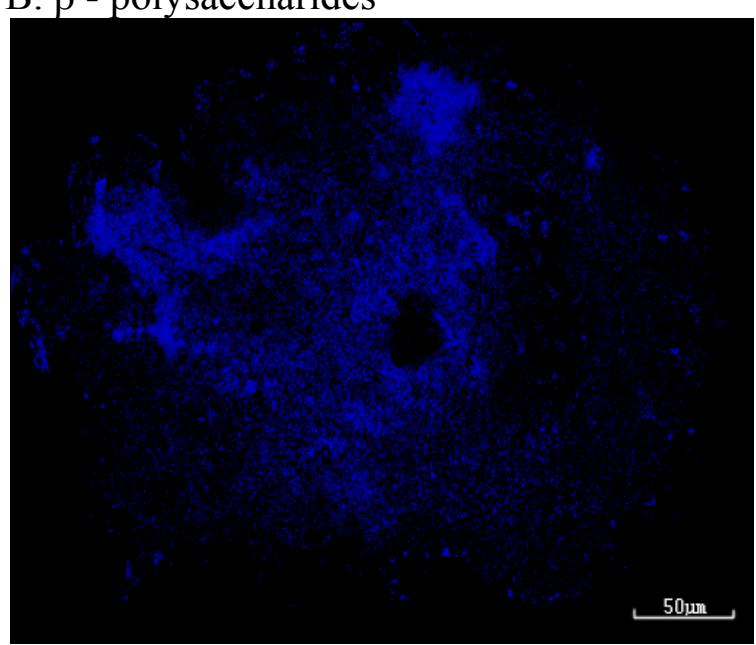

D. Cells

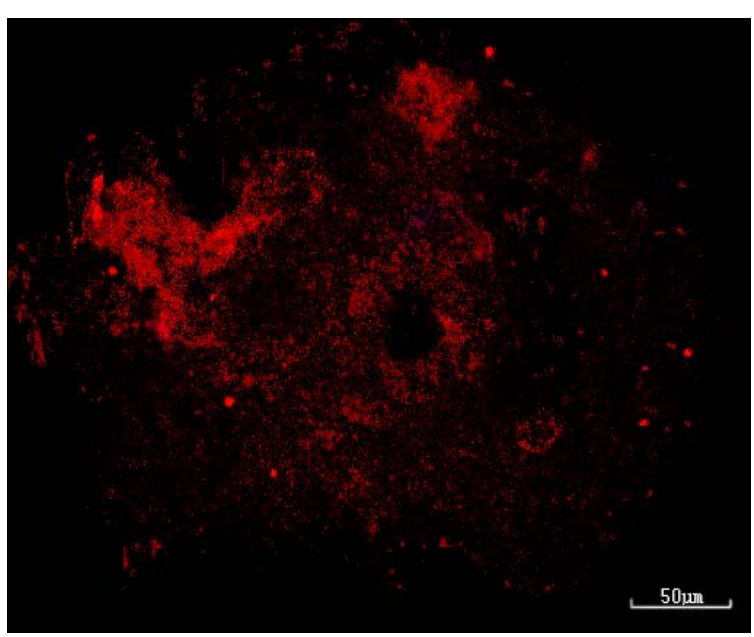

Fig. 9. Fluorescent of matrix compounds in the granule. A. Calcium ions (yellow - Calcium Green), B. $\beta-$ polysaccharides (blue - CW), C. Proteins (green - FITC), D. Cells (red - SYTO 63). Images were captured with the objective of 10x magnification 
An increase of cell hydrophobicity was also reported by Liu et al. (2002). Their results showed that hydrophobicity of granular sludge is nearly 2 times higher than that of conventional flocs. Additionally, Wang et al. (2005) reported that the shell of aerobic granules exhibited high hydrophobicity and this part of granules was composed mostly of EPS. In conclusion, it appears that an increase in exopolymeric protein content enhances relative cell hydrophobicity, thus contributing to aerobic granulation and stabilisation of granule structure.

\subsection{Distribution of EPS in granules structure}

Figure 8 shows the fluorescent staining of a $20-\mu \mathrm{m}$ cryosection taken from the middle of a granule (ca. $120 \mu \mathrm{m}$ below the surface). The granule diameter was $350 \mu \mathrm{m}$. A freshly sampled granule was stained before sectioning. Syto 63 was used as the nucleic acid stain (color red). Amine reactive dye (FITC) was used to stain proteins and other amine-containing compounds. Calcofluor white (CW) was used to stain $\beta$-polysaccharides, and Calcium Green was used to stain calcium ions.

According to the data presented in Figure 9C, proteins were concentrated mostly in a granule center, which is consistent with results obtained by Chen et al. (2007). A subsequent staining of nucleic acid with SYTO63 resulted in a number of signals from the granule center (Fig. 9D), suggesting that the center might be composed of dead cells, which have leaked proteins and other amine-containing compounds into the granule center. McSwain et al. (2005) reported that $\beta$-polysaccharides were located on the edge of granules and that the cells on the outer edge of granules were embedded in a large network of polysaccharides. In contrast, the data presented in Figure 9B show that the majority of $\beta$ - polysaccharides were located in granule center.

Furthermore, the presence of a zone without fluorescence was observed, especially on the outer shell of granules. It was observed that other components might have probably been present in that region, perhaps $\alpha$ - polysaccharides. Comparable results were obtained in a study carried out by Lee et al. (2010) reporting that the mature granules have a smooth outer surface composed mostly of lipids and $\alpha$ polysaccharide to minimise damage by granule-granule collision, and the granule core is composed of proteins and $\beta$-polysaccharides, which provide mechanical strength for the granule to resist shear stress.

Our results also indicate that the distribution of calcium ions is consistent with the distribution of proteins and polysaccharides (Fig. 9A). This conforms to literature data (Liu et al., 2007, Liu et al., 2010a). It was established that calcium cations probably participate in the process of combining polysaccharide chains and extracellular proteins, which creates a cross-linked EPS matrix.

A large pore was observed in the centre of the granule (Fig. 8, 9). According to Chiu et al. (2006), the presence of a large pore may enhance oxygen and mass transfer towards the granule core.

\section{CONCLUSIONS}

EPS expression since day 1 enables small flocks to combine. On day 3 small granule seeds, characterised by compact structure, can be observed in the reactor. Granule seeds quickly combine with each other, which is followed by rapid growth and formation of the first granules. At that time, no loosely-structured flocks are observed in the reactor. Therefore, it can be established that in oxygen reactors granulation takes place rapidly, over athe period of only 14 days, and leads to irreversible adhesion of bacterial cells thanks to the created EPS matrix. Proteins play a crucial role in biogranulation processes, as they increase the hydrophobicity of cells and enable mutual adhesion.

Furthermore, EPS improve sludge properties, in particular the volume index. The volume of excess sludges is low which can reduce the issues related to sewage sludge management. 
Microscopic results showed that EPS are located mostly in the center of the granule and in the subsurface layer. Proteins and $\beta$-polysaccharides are the major components of EPS.

We thank Ewa Matusecka, Ph.D, from the Institute of Oncology in Gliwice for letting us use the Leica Cryostat.

\section{REFERENCES}

Adav S.S., Lin J., Yang Z., Whiteley Ch.G., Lee D.J., Peng X.F., Zhang Z.P., 2010. Stereological assessment of extracellular polymeric substances, exo-enzymes, and specific bacterial strains in bioaggregates using fluorescence experiments. Biotechnol. Adv., 28, 255-280. DOI: 10.1016/j.biotechadv.2009.08.006.

Arrojo B., Mosquera-Corral A., Garrido JM., Mendez R., 2004. Aerobic granulation with industrial wastewater in sequencing batch reactors. Water Res., 3389-3399. DOI: 10.1016/j.watres.2004.05.002.

Chen M.Y., Lee D.J., Tay J.H., 2007. Distribution of extracellular polymeric substances in aerobic granules. Appl. Microbiol. Biotechnol., 73, 1463-1469. DOI: 10.1007/s00253-006-0617-x.

Chiu Z.C., Chen M.Y., Lee D.J., Tay S.T.-L., Tay J.H., Show K.Y., 2006. Diffusivity of oxygen in aerobic granules. Biotechnol. Bioeng., 94, 2006, 505-513. DOI: 10.1002/bit.20862.

Clesceri L.S., Greenberg A.E., Eaton A.D. (Eds.), 1999. Standard methods for the examination of water and wastewater. $20^{\text {th }}$ Edition. Amer. Public Health Assn., Amer. Water Works Assn., Water Pollut. Control Fed.

Dubois Dubois M.K., Gilles J.K., Hamilton J.K., Rebers P.A., Smith F., 1956. Procedure-phenol/sulfuric acid method. Anal. Chem., 28, 350-352.

Frølund B., Palmgren R., Keiding K., Nielsen P.H., 1996. Extraction of extracellular polymers form activated sludge using a cation exchange resin. Water Res., 30, 1749-1758. DOI: 10.1016/0043-1354(95)00323-1.

Gołaszewski J., Puzio-Idźkowska M., Stawiana-Kosiorek A., Załuski D., 2003. Statistic for naturalists. Wydawnictwo Uniwersytetu Warmińsko Mazurskiego (In Polish).

Kończak B., Miksch K., 2011a. Proces of aerobic granules formation: State of the art. Sci. Rev. Eng. Env. Sci., 51, 43-51.

Kończak B., Miksch K., 2011b. Influence of $\mathrm{Ca}^{2+}, \mathrm{Mg}^{2+}, \mathrm{Fe}^{3+}$ ions on the formaion of granular biomass. Przemyst Chemiczny, 90, 2002-2005.

Kong Y., Liu Y.-Q., Tay J.-H., Wong F.-S., Zhu J., 2009. Aerobic granulation in sequencing batch reactor with different reactor height/diameter ratios. Enzyme Microbial Technol., 45, 379-383. DOI: 10.1016/j.enzmictec.2009.06.014.

Laspidou CH.S., Rittman B.E., 2002. A united theory for extracellular polymeric substances, soluble microbial products, and active and inert biomass. Water Res., 36, 2711-2720. DOI: 10.1016/S0043-1354(01)00413-4.

Lee D-J., Chen Y-Y., Show K-Y., Whiteley Ch.G., Tay J-H., 2010. Advances in aerobic granule formation and granule stability in the course of storage and reactor operations. Biotechnol. Adv., 28, 919-934. DOI: 10.1016/j.biotechadv.2010.08.007.

Liu L., Gao D.W., Zhang M., Fu Y., 2010a. Comparison of $\mathrm{Ca}^{2+}$ and $\mathrm{Mg}^{2+}$ enhancing aerobic granulation in SBR. J. Hazard. Mater., 181, 382-387. DOI: 10.1016/j.jhazmat.2010.05.021.

Liu T., Yang S-F., Liu Q-S., Tay J-H., 2003. The role of cell hydrophobicity in the formation of aerobic granules. Curr. Microbiol., 46, 270-274. DOI: 10.1007/s00284-002-3878-3.

Liu T.-Q., Moy B., Kong Y.-H., Tay J.-H., 2010b. Formation, physical characteristic and microbial structure of aerobic granules in pilot-scale sequencing batch reactor for Real wastewater treatment. Enzyme Microbial Technol., 46, 520-525. DOI: 10.1016/j.enzmictec.2010.02.001.

Liu Y., Li Y., Wang Z-W., 2007. Calcium accumulation in acetate-fed aerobic granules, In: Liu Y. (Ed.), Wastewater Purification. Aerobic granulation in sequencing batch reactors. 223-237. DOI: 10.1201/9781420053685.ch13.

Liu Y., Tay J.H., 2004. State of the art of biogranulation technology for wastewater treatment. Biotechnol. Adv., 22, 533-563. DOI: 10.1016/j.biotechadv.2004.05.001.

Liu Y., Yang S-F., Liu Q-S., Tay J-H., 2003. The role of cell hydrophobicity in the formation of aerobic granules, Curr. Microbiol., 46, 0270-0274. DOI: 10.1007/s00284-002-3878-3. 
McSwain B.S., Irvine R.L., Hausner M., Wilderer P.A., 2005. Composition and distribution of extracellular polymeric substances in aerobic flocs and granular sludge. Appl. Environ. Microbiol., 71, 1051-1057. DOI: 10.1128/AEM.71.2.1051-1057.2005.

Morgenroth E., Sherden T., van Loosdrecht M.C.M., Heijnen J.J., Wilder P.A., 1997. Aerobic granular sludge in a sequencing batch reactor. Water Res., 31, 3191-3194. DOI: 10.1016/S0043-1354(97)00216-9.

Rosenberg M., Gutnick D., Rosenberg E., 1980. Adherence of bacteria to hydrocarbons: A simple method for measuring cellsurface hydrophobicity. FEMS Microbiol. Lett., 9, 29-33. DOI: 10.1111/j.15746968.1980.tb05599.x.

Seviour T., Pijuan M., Nicholson T., Keller J., Yuan Z., 2009. Gel-forming exopolysaccharides explain basic differences between structures of aerobic sludge granules and floccular sludges. WaterRes., 43, 4469-4478. DOI: 10.1016/j.watres.2009.07.018.

Tian Y., 2008. Behaviour of bacterial extracellular polymeric substances from activated sludge: A review. Int. J. Environ. Pollut., 32, 78-89. DOI: 10.1504/IJEP.2008.016900.

Wang Z., Liu L. Yao J., Cai W., 2006. Effects of extracellular polymeric substances on aerobic granulation in sequencing batch reactors. Chemosphere, 63, 1728-1735. DOI: 10.1016/j.chemosphere.2005.09.018.

Wang Z-W., Liu Y., Tay J-H., 2005. Distribution of EPS and cell surface hydrophobicity in aerobic granules. Appl. Microbiol. Biotechnol., 69, 469-73. DOI: 10.1007/s00253-005-1991-5.

Wojnowska-Baryła I., Cydzik-Kwiatkowska A., Szatkowski M., Gutowski Ł., 2010. Granulation of activated sludge in SBR reactor. Biotechnologia, 1, 161-169.

Zhang L.L., Feng X.X., Zhu N.W., Chen J.M., 2007. Role of extracellular protein in the formation and stability of aerobic granules. Enzymes Microb. Technol., 41, 551-557. DOI: 10.1016/j.enzmictec.2007.05.001.

Received 16 May 2012

Received in revised form 21 November 2012 Accepted 21 November 2012 